UDC 346.2:334.732.2

DOI https://doi.org/10.32849/2663-5313/2021.8.05

\title{
Bogdan Derezyanko,
}

Doctor of Law, Professor, Chief Scientific Researcher, F. H. Burchak Scientific Research Institute of Private Law and Entrepreneurship of the National Academy of Legal Sciences of Ukraine, 23-a, Raievskoho street, Kyiv, Ukraine, postal code 02000,ndippp@adamant.net

ORCID: orcid.org/0000-0001-7408-8285

Scopus: https://wrow.scopus.com/authid/detail.uri?authorId $=57200123478$

Publons: https://publons.com/researcher/2454637/bogdan-derevyanko/

\section{Andrii Zakharchenko,}

Doctor of Law, Associate Professor, Head of the Research Laboratory of Public Security of Local Communities, Donetsk State University of Internal Affairs, 89, Lunina avenue, Mariupol, Donetsk region, Ukraine, postal code 87500, an_zaharchenko@ukr.net

ORCID: orcid.org/0000-0002-6359-2475

Scopus: https://wwr.scopus.com/authid/detail.uri?authorId $=57217741037$

Derevyanko, Bogdan, Zakharchenko, Andrii (2021). The necessity of changing the legal status of a credit union. Entrepreneurship, Economy and Law, 8, 35-41.

\section{THE NECESSITY OF CHANGING THE LEGAL STATUS OF A CREDIT UNION}

Abstract. Purpose. The article substantiates proposals for changes in the legal status of credit unions based on the analysis of the provisions of the Ukrainian legislation on credit unions and the practice of their activities. Research methods. The paper is prepared by applying the general research and special methods of scientific cognition. The authors used the methods of analysis and synthesis, comparative legal and historical legal, which allowed identifying inconsistencies in the legal status of the credit union with modern realities and proposing changes.

Results. Credit unions are specific economic entities. They have a non-commercial status and are financial institutions with exclusive competence and tasks to provide inexpensive credit resources to their members and other persons. Credit unions in a simplified form act as follows: members of the credit union give it money in the form of initiation, compulsory shares, and other fees in the amount, time, and the manner determined by the charter of the credit union; the union may acquire ownership of government securities and bonds of international financial organizations placed on the territory of Ukraine; members of the credit union or other persons can receive loans at the expense of its property; the credit union may receive payments for providing loans and other services to its members, as well as income from other types of statutory activities, may receive monetary and other property donations, charitable contributions, grants, free technical assistance, as well as other receipts not prohibited by law from Ukrainian and foreign citizens (subjects), business entities and the state.

Conclusions. It was determined that the main task of credit unions was to provide their members (potential or real entrepreneurs) with cheap credit resources, and additionally - other persons. As a result, credit resources from Ukrainian credit unions are provided in small volumes at higher interest rates than commercial banks. Credit unions compete with pawnshops in many cases, providing microcredits secured by household appliances, precious metal products, etc. The simplest way to remedy the situation was proposed - to deprive credit unions of non-commercial status with the possibility of obtaining benefits in taxation of profits by those credit unions that provide at least $50 \%$ of their loans to their members to create and develop their own business at interest not exceeding the average interest on loans of twenty largest commercial banks of Ukraine, determined as of January 1 of the corresponding calendar year.

Key words: credit unions, financial institutions, contributions (deposits), non-profit organizations, credit resources, income tax, commercial banks, pawnshops.

\section{Introduction}

The modern world market system is complex and ramified. To obtain competitive advantages within the framework of this system, business entities have to act proactively, non-linearly, constantly changing directions, forms and methods. The advantages provided by the legislation of various states for business entities formed using various organizational and legal forms are important. At the same time, 
in many states and sectors of the economy, it is quite common for business entities to permanently change their organizational and legal forms depending on economic feasibility. One of the specific organizational and legal forms with its own advantages and features is a credit union. According to the legislation of Ukraine, credit unions are specific entities that provide financial services - business entities with a special status. The activities of such entities are regulated by the Law of Ukraine "On Credit Unions” № 2908-III dated December 20,2001 , according to which a credit union is a non-profit organization founded by individuals, trade unions, their associations on a cooperative basis to meet the needs of its members in mutual lending and the provision of financial services through pooled monetary contributions from credit union members (Verkhovna Rada of Ukraine, 2002). Despite the existence in Ukraine of an official definition of a credit union and the regulation of the peculiarities of its activities in a special law, there are many issues related to various elements of the legal status of such entities.

Analysis of recent research and publications. Certain elements of the legal regime of credit unions' activities were the subject of researches of many Ukrainian academic lawyers and economists. They are as follows: B. Dadashev, O. Hrytsenko (Dadashev, Hrytsenko, 2010; Hrytsenko, 2005, pp. 75-82), O. Dobrovolska (Dobrovolska, 2016, pp. 536-540), A. Dukhnevych (Dukhnevych, 2002, pp. 304-308; Dukhnevych, 2008), O. Honcharenko (Honcharenko, Dzemishkevych, 2014, pp. 46-56), V. Honcharenko (Honcharenko, 1997), V. Manziuk, V. Zaborovskyi (Manziuk, Zaborovskyi, 2014, pp. 129-135), K. Masliaieva (Masliaieva, 2009; Masliaieva, 2010), O. Mishchuk (Mishchuk, 2015), V. Pokhyliuk (Pokhyliuk, 2008, pp. 317-322), V. Poliukhovych (Poliukhovych, 2012), A. Pozhar (Pozhar, 2007, pp. 335-344), V. Roienko (Roienko, Bozhenko, Ivanova, 2016, pp. 874-876), N. Savchuk, O. Zolotarova (Savchuk, Zolotarova, 2019, pp. 204-208), A. Semenoh (Semenoh, 2011, pp. 139-148), N. Slavova (Slavova, 2007, pp. 147-150; Slavova, 2010; Slavova, 2011), H. Stoianov (Stoianov, 2016), O. Yelisieieva (Yelisieieva, Stoianov, 2013, pp. 40-43), O. Zubatenko (Zubatenko, 2009, pp. 30-34) and others. At the same time, the vast majority of research was conducted in the framework of economic sciences. In addition, the majority of researchers analyzed the elements of the current legal status of credit unions that are enshrined in law. Changes in the legal status of credit unions are rarely proposed by authors. Therefore, the study of the legal status of credit unions and the legal status of their activities does not lose its relevance.

Research methods. The paper is prepared by applying the general research and special methods of scientific cognition. The authors used the methods of analysis and synthesis, comparative legal and historical legal, which allowed identifying inconsistencies in the legal status of the credit union with modern realities and proposing changes.

The purpose of the research is to substantiate proposals for changes in the legal status of credit unions based on the analysis of the provisions of the Ukrainian legislation on credit unions and the practice of their activities.

2. General provisions on the legal status of a credit union

The idea of the organizational and legal form of a credit union is to satisfy its members' interests. In this regard, the first credit unions created about 100 years ago in different countries in a form similar to modern one had common features with mutual aid funds. They provided loans to some of their members at the expense of deposits of others. It was not about making a profit then. The idea meant that the person "stood in line" while those who had previously become a member of the credit union (including through its contribution) took out a loan and then one took out the loan at the expense of contributions from persons who became members of the credit union later. To implement such a scheme, a credit union had to have a large number of members. Because of these goals, most of the participants in the first credit unions had some similarities with "financial pyramids". However, unlike the "financial pyramid", a modern credit union, following the requirements of the current legislation, undergoes state registration, receives the status of a financial institution and a license from the National Bank of Ukraine, acting based on the charter; it is managed by the general meeting of the members of the credit union, the supervisory board of the credit union, the board of the credit union. One member of a credit union or a group of them cannot appropriate all the property or money of a credit union like in a "pyramid scheme". The legal status of a credit union differs significantly from the legal status of other financial institutions and even more from the main business entities.

A credit union is a financial institution, which means that it has certain tasks and competencies that differ from those that may have subjects of the main (primary) business level. The exclusive activity of a credit union is the provision of financial services under the above-mentioned law. The activity of the credit union is associated with the receipt 
of funds and, in a simplified form, can be represented as follows: at the conditional first stage, the members of the credit union give it money in the form of initial, compulsory shares, and other costs in the amount, terms and the manner determined by the charter of the credit union. This forms the property basis of the credit union's activities. At this stage, a credit union can acquire ownership of government securities and bonds of international financial organizations placed on the territory of Ukraine. At the conditional second stage, members of the credit union or other persons can receive loans at the credit union's property expense. For members of a credit union, preferential loan terms are applied compared to the general loan terms. At the conditional third stage of the credit union's activity, it may receive payment for providing its members with loans and other services, as well as income from other types of statutory activities, may receive monetary and other property donations, charitable contributions, grants, gratuitous technical assistance, as well as other income not prohibited by law from both Ukrainian and foreign citizens (subjects), business entities and states. These stages are conditional since the given sequence is not mandatory due to the permanence of the credit union's activity process. The obligation of such a sequence is of a private nature. It is kept in making contributions, obtaining a loan, paying for it by one individual member of the credit union, receiving a loan, and paying for it by one person who is not a credit union member.

In addition to the property of the credit union itself, it can also use contributions on the deposit accounts of its members, which belong to them based on the right of private property. These funds are used to provide loans to members of the credit union. If there are temporarily free funds from members of the credit union, they can be placed by the union on deposit accounts in banks licensed to work with citizens' deposits and in the united credit union, as well as in state securities (Derevianko, 2021, pp. 46-47).

3. Actual features of the credit union's activities

In countries with a developed modern sphere of financial services, including those which are provided by credit unions, the latter attract money in the form of contributions from their members at low-interest rates and lend this money to other members at slightly higher interest rates. Usually, in such countries, union members do not manage to earn a lot on deposits. However, this is not their main goal when joining a credit union. People are more likely to join credit unions to obtain loans at low-interest rates in the future (Derevianko, 2021, p. 47). For these reasons, the success of credit unions is directly dependent on the number of their members. In the early 1990s, the first credit unions on the territory of the former Soviet republics appeared in Moscow and St. Petersburg, and a few years later - in Kyiv. Part 1 of Article 6 "Creation of a credit union" of the Law of Ukraine "On Credit Unions" stipulates that the number of founders (members) of a credit union may not be less than 50 people (Verkhovna Rada of Ukraine, 2002). The first credit unions had thousands of members. Under such conditions, many people among the very members and other persons want to get the credit resources they need.

The activity of credit unions as fullfledged subjects of economic law has the goal of realizing public law interests - increasing the welfare of citizens of the state or foreigners permanently residing in this state, and, consequently, the welfare of the state itself. However, the credit union's activities are mainly aimed at achieving the private interests of credit union members and other persons. These interests are directly related to obtaining credit resources by them. It is also important to ensure the private interests of credit union members in receiving fraction of revenue from its activities.

As noted, the members of a credit union can be citizens, foreigners, and stateless persons permanently residing in the state's territory. The provision of part 1 of Article 6 "Creation of a credit union" determines that the members of the credit union must be united at least according to one of the above criteria: 1 ) to have a common place of work or study; 2) to be affiliated to one trade union, an association of trade unions, another public or religious organization; $3)$ to live in the same village, town, city, district, region (Verkhovna Rada of Ukraine, 2002). The above indicates the direction of implementation by the credit union of the public interests of the state of Ukraine, since foreigners who do not have a place of work or study in Ukraine, do not belong to a trade union or other organization, do not live in a village, town, city, district, region of Ukraine cannot become the members of the credit union.

The main task of a credit union is to meet the needs for credit resources, and generating income is a secondary or related task. The fee for the provided credit resources is not distributed among the members of the credit union, except for payments on deposits. Still, it is directed at fulfilling the main task of the credit union's activities - the provision of financial services, including, first, lending services.

Ukraine is a country with poor financial services market. Therefore, objective economic laws are in effect in this market, but there are often certain features. The first credit 
unions were formed more than 100 years ago as an alternative to commercial banks. It was planned that members of credit unions would get credit resources on better terms than they would have done in commercial banks. However, the income from providing money to a credit union as a deposit was planned to be less than the same in commercial banks. However, the amount of profit, or more precisely, the "final financial result", even if it was planned to be less than that of the bank, was not less by much. The reason is that, unlike a commercial bank, a credit union is a non-profit organization and does not pay income tax.

In fact, in countries with a low level of the financial system, including Ukraine, the situation has developed differently. Ukrainian credit unions often offer slightly higher interest rates on deposits and loans than banks. This is especially true for loans for individuals who are not members of a credit union. In general, Ukrainian credit unions have occupied their niche in microcredit, providing loans for no more than a few thousand hryvnias. Often such loans are provided on the security of household appliances, jewelry, etc. In such cases, credit unions are competitors of pawnshops (Derevianko, 2021, p. 47). In other words, credit unions do not pay income tax, and loan rates are often set higher than those of commercial banks.

4. Hybridity and inconsistency of the nonprofit status of a credit union

The status of a non-profit organization in a credit union and many other non-profit business entities looks hybrid and contradictory. In Ukraine, two criteria are applied for recognition or non-recognition of a business entity as non-profitable. The first is the actual receipt of profit, i.e., monetary or material values that exceed expenses. In the first lines of subparagraph 134.1.1 of paragraph 134.1 of Article 134 "Object of taxation" of the Tax Code of Ukraine, the object of taxation with profit tax is defined as "profit with a source of origin from Ukraine and abroad, which is determined by adjusting (increasing or decreasing) the financial result before taxation (profit or loss), determined in the financial statements of the enterprise under national regulations (standards) of accounting or international financial reporting standards, for differences arising under the provisions of this Code" (Verkhovna Rada of Ukraine, 2011). As a follow-up to this provision, paragraph 3 of part one "General Provisions" of the national accounting regulation (Standard) 1 "General requirements for financial reporting" defines profit as the amount by which income exceeds related expenses (Natsionalne polozhennia (standart) bukhhalterskoho obliku 1 "Zahalni vymohy do finansovoi zvitnosti", 2013). Thus, any profitable activity of any business entity indicates that it has the first criterion for recognizing it as profitable. The same credit union receives money that usually exceeds its expenses. However, there is a second criterion in the legislation of Ukraine and the current theory. In the presence of this criterion, even generating income or profit allows the subject to be recognized as a non-profit organization. This criterion is the intended use of the money received by the subject exclusively to ensure the implementation of its main activities.

Confirmation of the existence of this criterion is the indication by subparagraph 133.4 .2 of paragraph 133.4 of Article 133 "Taxpayers" of Section III "Corporate Income Tax" of the Tax Code of Ukraine that the income (profits) of a non-profit organization is used exclusively to finance the expenses for the maintenance of such a non-profit organization, the implementation of the goal (goals, objectives) and areas of activity defined by its constituent documents (Verkhovna Rada of Ukraine, 2011). The same is found in acts of special legislation that define the specifics of the legal status of certain types of non-profit business entities.

By applying this second criterion, credit unions and commodity exchanges, chambers of commerce, religious organizations, charitable foundations, political parties, and other entities receive money that is often referred to by law as income. Paragraph 1 of Article 1 of the Law of Ukraine "On Credit Unions" stipulates that a credit union is a non-profit organization. Paragraph 2 of the same article provides that a credit union is a financial institution which exclusive activity is the provision of financial services provided for by the 2001 Law of Ukraine "On Credit Unions" (the issue arises "Can financial services be provided free of charge without the purpose of making a profit?") (Derevianko, 2013, p. 239). By their very nature, all types of financial activities involve achieving profitability, and therefore, at least generating income. The non-profit status of financial institutions, in general, is something superfluous and incomprehensible.

In many countries of the world, there is a division of business entities into undertakings and non-profit business entities. At the same time, a non-profit organization's status is considered a benefit or state support, which should be earned and which should be met. It is unlikely that today Ukraine is such a rich state (especially considering more than seven years of aggression, hybrid warfare, loss of territory as a result of the annexation attempt, as well as the global coronavirus pandemic, corruption in various echelons of power, etc.) to leave bene- 
fits for a significant number of types of business entities, especially in the field of financial activities. In the second group of countries, there is no division of business entities into commercial and non-commercial (non-profit) ones. All business entities have the same status (a set of rights and obligations) to the fiscal authorities. They pay income tax or its analogs in case of making a profit and do not pay it in case of non-receipt. In the latter case, they can apply to the state for help. Obviously, this option is more suitable for Ukraine. Earlier, we proposed applying the basic and unified criterion for determining income status to higher education institutions (Derevianko, 2012, p. 118). To a greater extent, such a proposal is relevant for financial institutions. It is incorrect that credit institutions have a non-profit status due to their fierce competition with commercial banks and pawnshops (the latter are also formed in organizational and legal forms that are inconvenient for the founders but convenient for their counterparties). Banks and pawnshops are payers of income tax and do not have any tax or other benefits.

\section{Conclusions}

The Ukrainian state requires significant financial resources. Therefore, new taxes are introduced, the cost of utilities increases, violations of the rules for exporting goods and other valuables abroad and importing them to Ukraine are criminalized, etc. We have previously raised the question that should be repeated: "why should the state provide financial benefits to credit unions, which in general failed to cope with the task for which they were introduced into the legal field of Ukraine?" (Derevianko, 2021, p. 48). Their main task was to provide their members (potential or real entrepreneurs) with cheap credit resources, and additionally - other persons. As a result, credit resources from Ukrainian credit unions are provided in small amounts at higher interest rates than is done by commercial banks. Moreover, credit unions compete with pawnshops in many cases, providing micro-loans secured by household appliances, precious metal products, etc. At the same time, the activities of credit unions are often accompanied by violations, and there are cases of initiating criminal proceedings against the activities of individual credit unions and their members. On the other hand, the receipt by a credit union of income from activities inherent in pawnshops is positive both for the union itself and its members and for the state economy. The disadvantage is the absence, unlike a pawnshop, of income tax amounts received from a credit union to the state budget of Ukraine. At the same time, the pawnshop is also limited in choosing the organizational and legal form of the business entity. At the same time, credit unions provide loans at low-interest rates to their members and others. Therefore, it would be not feasible to deprive them of state support.

The simplest way to remedy the situation was proposed - to deprive credit unions of non-commercial status with the possibility of obtaining benefits in taxation of profits by those credit unions that provide at least $50 \%$ of their loans to their members to create and develop their own business at interest not exceeding the average interest on loans of twenty the largest commercial banks of Ukraine, determined as of January 1 of the corresponding calendar year (Derevianko, 2021, p. 48). It is clear that as a result of more thorough research, other organizational and legal forms of financial institutions can be invented that can ensure the implementation of private and public interests and other options for improving the components of the legal status of credit unions. The following scientific research should be aimed at this issue.

\section{References:}

Dadashev, B.A., Hrytsenko, O.I. (2010). Kredytni spilky v Ukraini: navchalnyi posibnyk [Credit unions in Ukraine: textbook]. Kyiv: Tsentr uchbovoi literatury (in Ukrainian).

Derevianko, B.V. (2012). Komertsiinyi status subiektiv hospodariuvannia, shcho nadaiut posluhy u sferi osvity [Commercial status of economic entities providing educational services]. Pidpryiemnytstvo, hospodarstvo i pravo - Entrepreneurship, Economy and Law, no. 8, pp. 114-118 (in Ukrainian).

Derevianko, B.V. (2021). Osoblyvosti nadannia finansovykh posluh kredytnymy spilkamy [Features of providing financial services by credit unions]. Zakonodavstvo Ukrainy pro finansovi posluhy: pytannia adaptatsii do prava Yevropeiskoho Soiuzu: materialy Naukovo-praktychnoho kruhloho stolu, Sumy, 15 January 2021 r. Sumy: Sumskyi derzhavnyi universytet, pp. 46-49 (in Ukrainian).

Derevianko, B.V. (2013). Posluhy u sferi osvity: pravove rehuliuvannia: monohrafiia [Educational services: legal regulation: monograph]. Donetsk: Kalmius (in Ukrainian).

Dobrovolska, O.V. (2016). Prohrama zakhystu vkladiv kredytnykh spilok [Credit Union Deposit Protection Program]. Ekonomika ta suspilstvo - Economy and Society, no. 2, pp. 536-540 (in Ukrainian).

Dukhnevych, A.V. (2008). Pravove stanovyshche kredytnykh spilok v Ukraini: monohrafiia [Legal status of credit unions in Ukraine: monograph]. Lutsk: Volynskyi natsionalnyi universytet im. L. Ukrainky (in Ukrainian).

Dukhnevych, A.V. (2002). Yurydychna pryroda kredytnoi spilky [The legal nature of the credit union]. Visnyk Lvivskoho instytutu vnutrishnikh sprav, no. 3, pp. 304-308 (in Ukrainian). 
Honcharenko, O.O., Dzemishkevych, I.O. (2014). Finansovi zvity kredytnykh spilok ta osoblyvosti yikh analizu [Financial statements of credit unions and features of their analysis]. Finansovyi prostir - Financial Space, no. 1(13), pp. 46-56 (in Ukrainian).

Honcharenko, V.V. (1997). Kredytni spilky yak finansovi kooperatyvy: mizhnarodnyi dosvid ta ukrainska praktyka: monohrafiia [Credit unions as financial cooperatives: international experience and Ukrainian practice: monograph]. Kyiv: Naukova dumka (in Ukrainian).

Hrytsenko, O.I. (2005). Kryterialni pokaznyky diialnosti kredytnoi spilky [Criteria indicators of credit union activity]. Derzhava ta rehiony. Seriia "Ekonomika ta pidpryiemnytstvo" - State and regions. Series "Economics and Business", no. 1, pp. 75-82 (in Ukrainian).

Manziuk, V.V., Zaborovskyi, V.V. (2014). Hospodarsko-pravovi zasady diialnosti kredytnykh spilok [Economic and legal principles of credit unions activity]. Visegrad Journal on Human Rights, no. 2, pp. 129-135 (in Ukrainian).

Masliaieva, K.V. (2009). Hospodarsko-pravove zabezpechennia funktsionuvannia rynku finansovykh posluh $v$ Ukraini [Economic and legal support of function of financial services market in Ukraine] (Extended abstract of candidate's thesis). Kharkiv (in Ukrainian).

Masliaieva, K.V. (2010). Hospodarsko-pravove zabezpechennia funktsionuvannia rynku finansovykh posluh Ukrainy: monohrafiia [Economic and legal support of function of financial services market in Ukraine: monograph]. Kharkiv: FINN (in Ukrainian).

Mishchuk, O.V. (2015). Osoblyvosti diialnosti kredytnykh spilok v Ukraini ta napriamy yii vdoskonalennia [Features of credit unions activity in Ukraine and areas of improvement]. Ekonomichnyi visnyk: zbirnyk naukovykh prats - Economic bulletin: a collection of scientific papers. Uman: FOP Zhovtyi O.O., iss. 9 (in Ukrainian).

Natsionalne polozhennia (standart) bukhhalterskoho obliku 1 "Zahalni vymohy do finansovoi zvitnosti”: zatverdzhenyi Nakazom Ministerstva finansiv Ukrainy vid 7 liutoho 2013 roku № 73 [National Regulation (Standard) of Accounting 1 "General requirements for financial reporting": approved by the order of the Ministry of Finance of Ukraine on February 7, 2013 № 73]. Retrieved from: https://zakon.rada.gov.ua/ laws/show/z0336-13\#Text (in Ukrainian).

Pokhyliuk, V.V. (2008). Kredytni spilky: yikh mistse i rol u transformatsii bankivskoi systemy v umovakh dotry-mannia ekonomichnoi bezpeky finansovykh struktur [Credit unions: their place and role in transformation of the banking system in the conditions of observance of economic security of financial structures]. Problemy $i$ perspektyvy rozoytku bankizskoi systemy Ukrainy - Problems and prospects of banking system development of Ukraine, no. 23, pp. 317-322 (in Ukrainian).

Poliukhovych, V.I. (2012). Derzhavne rehuliuvannia fondovoho rynku Ukrainy: hospodarsko-pravovyi mekhanizm: monohrafiia [State regulation of the stock market of Ukraine: economic and legal mechanism: monograph]. Kyiv: NDI pryvatnoho prava i pidpryiemnytstva NAPrN Ukrainy (in Ukrainian).

Pozhar, A.A. (2007). Finansovi aspekty funktsionuvannia kredytnykh spilok [Financial aspects of functioning of credit unions]. Problemy i perspektyoy rozoytku bankivskoi systemy Ukrainy - Problems and prospects of banking system development of Ukraine. Sumy: UABS NBU, vol. 20, pp. 335-344 (in Ukrainian).

Roienko, V.V., Bozhenko, A.S., Ivanova, A.S. (2016). Suchasnyi stan ta problemy funktsionuvannia kredytnykh spilok v Ukraini [Current status and problems of credit unions activity in Ukraine]. Hlobalni ta natsionalni problemy ekonomiky - Global and national economic problems, no. 10, pp. 874-876 Retrieved from: https://essuir.sumdu.edu.ua/handle/123456789/83090 (in Ukrainian).

Savchuk, N.V., Zolotarova, O.V. (2019). Rozvytok kredytnykh spilok yak chynnyk sotsialnoi ta diialnistnoi mobilnosti v ukrainskomu suspilstvi [Development of credit unions as a factor of social and industrial mobility in Ukrainian society]. Naukovyi visnyk Khersonskoho derzhavnoho universytetu. Seriia "Ekonomichni nauky" - Scientific Bulletin of Kherson State University. Series "Economic Sciences", no. 33, pp. 204-208. DOI: 10.32999/ksu2307-8030/2019-33-40 (in Ukrainian).

Semenoh, A.Yu. (2011). Diialnist nebankivskykh finansovykh ustanov u konteksti ekonomichnoho zrostannia [Activity of unbank financial institutions in the context of economic increase]. Visnyk Zaporizkoho natsionalnoho universytetu. Seriia "Ekonomichni nauky" - Bulletin of Zaporizhzhia National University. Series "Economic Sciences", no. 1(1), pp. 139-148 (in Ukrainian).

Slavova, N.O. (2010). Hospodarsko-pravovyi status kredytnykh spilok [The legal status of credit unions] (Extended abstract of candidate's thesis). Donetsk: Instytut ekonomiko-pravovykh doslidzh of NAN Ukrainy (in Ukrainian).

Slavova, N.O. (2011). Hospodarsko-pravovyi status kredytnykh spilok: monohrafiia [The legal status of credit unions: monograph]. Donetsk: Donetskyi natsionalnyi universytet (in Ukrainian).

Slavova, N.O. (2007). Kredytni spilky: poniattia, klasyfikatsiia, zahalna kharakterystyka [Credit unions: concept, classification, general characteristics]. Visnyk hospodarskoho sudochynstva - Bulletin of Commercial Litigation, no. 5, pp. 147-150 (in Ukrainian).

Stoianov, H.S. (2016). Udoskonalennia mekhanizmu rozvytku kredytnykh spilok Ukrainy [An improvement of mechanism of development of credit unions of Ukraine] (Extended abstract of candidate's thesis). Sumy: Sumskyi derzhavnyi universytet (in Ukrainian).

Verkhovna Rada of Ukraine (2011). Podatkovyi kodeks Ukrainy: Zakon Ukrainy vid 2 hrudnia 2010 roku № 2755-VI [Tax Code of Ukraine: Law of Ukraine of December 2, 2010 № 2755-VI]. Vidomosti Verkhovnoi Rady Ukrainy - Bulletin of Verkhovna Rada of Ukraine, no. 13-17, art. 112 (in Ukrainian). 
Verkhovna Rada of Ukraine (2002). Pro kredytni spilky: Zakon Ukrainy vid 20 hrudnia 2001 roku № 2908-III [On credit unions: Law of Ukraine of December 20, 2001 № 2908-III]. Vidomosti Verkhovnoi Rady Ukrainy - Bulletin of Verkhovna Rada of Ukraine, no. 15, art. 101 (in Ukrainian).

Yelisieieva, O.K., Stoianov, H.S. (2013). Suchasnyi stan rozvytku kredytnykh spilok Ukrainy [The current state of development of credit unions in Ukraine]. Ekonomist - Ekonomist, no. 4, pp. 40-43 (in Ukrainian).

Zubatenko, O.M. (2009). Kredytna spilka yak uchasnyk vidnosyn u sferi hospodariuvannia [Credit union as a participant of relations in the field of business]. Ekonomika ta pravo - Economics and Law, no. 1, pp. 30-34 (in Ukrainian)

\section{Богдан Деревянко,}

доктор юридичних наук, професор, головний науковий співробітник, Науково-дослідний інститут приватного права і підприємничтва імені академіка Ф. Г. Бурчака Начіональної академї правових наук Украӥни, вулиия Раєвського, 23-а, Київ, Украӥна, індекс 02000, ndippp@adamant.net

ORCID: orcid.org/0000-0001-7408-8285

Scopus: https://wror.scopus.com/authid/detail.uri?authorId $=57200123478$

Publons: https://publons.com/researcher/2454637/bogdan-derevyanko/

\section{Андрій Захарченко,}

доктор юридичних наук, доцент, завідувач науково-дослідної лабораторії публічної безпеки громад, Донеиький державний університет внутрішніх справ, проспект Луніна, 89, Маріуполь, Донецька область, Україна, індекс 87500, an_zaharchenko@ukr.net

ORCID: orcid.org/0000-0002-6359-2475

Scopus: https://wror.scopus.com/authid/detail.uri?authorId=57217741037

\section{ПРО НЕОБХІДНІСТЬ ЗМІН У ПРАВОВОМУ СТАТУСІ КРЕДИТНОЇ СПІЛКИ}

Анотація. Мета - на основі аналізу положень законодавства України про кредитні спілки та практики їх діяльності обгрунтувати пропозиції щодо змін у правовому статусі кредитних спілок. Методи дослідження. Статтю підготовлено з використанням загальнонаукових і спеціальних методів наукового пізнання. Зокрема, застосовувалися методи аналізу й синтезу, порівняльно-правовий та історично-правовий методи, що дало змогу виявити у правовому статусі кредитної спілки невідповідності сучасним реаліям та запропонувати зміни для поліпшення цієї ситуації.

Результати. Кредитні спілки є специфічними суб'єктами господарювання, оскільки вони мають неприбутковий статус і водночас $є$ фінансовими організаціями з виключною компетенцією та завданням - надавати недорогі кредитні ресурси своїм членам та іншим особам. Кредитні спілки у спрощеному вигляді діють так: члени кредитної спілки надають їй гроші у вигляді вступних, обов'язкових пайових та інших внесків у розмірах, строки й у порядку, що визначені статутом кредитної спілки; спілка може набувати у власність державні цінні папери та облігації міжнародних фінансових організацій, які розміщуються на території України; члени кредитної спілки або інші особи можуть отримувати кредити за рахунок ії майна; кредитна спілка може отримувати плату за надання своїм членам кредитів та інших послуг, доходи від провадження інших видів статутної діяльності, грошові та інші майнові пожертви, благодійні внески, гранти, безоплатну технічну допомогу, а також інші надходження, не заборонені законодавством, як від українських, так і від іноземних громадян (підданих), суб'єктів господарювання та держав.

Висновки. Визначено, що основним завданням кредитних спілок є забезпечення в дешевих кредитних ресурсах своїх членів - потенційних або реальних підприємців, а також інших осіб (додатково). Так, кредитні ресурси від українських кредитних спілок надаються в невеликих обсягах під вищі відсотки, ніж це робиться комерційними банками, а в багатьох випадках кредитні спілки $€$ конкурентами ломбардів, оскільки надають мікрокредити під заставу побутової техніки, виробів із дорогоцінних металів тощо. Запропоновано найпростіший варіант виправлення ситуації - позбавити кредитні спілки некомерційного статусу з можливістю отримання пільги в оподаткуванні прибутку тими кредитними спілками, які не менш ніж 50\% своїх кредитів надають своїм членам для започаткування й розвитку власного бізнесу під відсотки, що не перевищують середній відсоток за кредитами у 20 найбільших комерційних банках України, що визначений на 1 січня відповідного календарного року.

Ключові слова: кредитні спілки, фінансові установи, внески (вклади), неприбуткові організації, кредитні ресурси, податок на прибуток, комерційні банки, ломбарди.

The article was submitted 01.08.2021

The article was revised 23.08.2021

The article was accepted 21.09.2021 